\title{
Problems and countermeasures of college English teaching
}

\author{
transformation in the era of Internet+
}

\author{
Yu Yanli \\ College of Foreign Language, Jilin Agricultural University, Jilin, China
}

Keywords: College English; New media; Teaching transformation

\begin{abstract}
The advent of the era of Internet information makes the traditional college English teaching face many challenges and opportunities. At present, the traditional teaching methods can't meet the needs of the new period. In order to adapt to the characteristic of new era, college English teaching is undergoing transformation from traditional teaching mode to networked teaching mode. This paper discusses the problems existing in college English teaching mode and strategy to improve college English teaching under the background of new media, including thoroughly changing the traditional teaching idea, further improving teaching methods, enriching the teaching content, blending to strengthen the construction of college English teachers, comprehensively improving the existing methods of testing and evaluation system and reasonably develop repository, expecting to cultivate the new talent not only catering to the need of society in the era of new media but also mastering professional knowledge of English and cultural quality.
\end{abstract}

\section{Introduction}

College English teaching reform was announced officially by the Ministry of Education in 2003. The release and implementation of "College English Curriculum Requirements" (hereinafter referred to as CECR, Higher Education Department of Ministry of Education, 2007) indicate a direction for the reform of college English teaching. CECR points out that on the basis of inheriting good part of the existing teaching mode, supported by modern information technology especially network technology, college English teacher should make English teaching develop towards personalized study and active learning direction, not restricted by time and place of learning. Along with the wide application of mobile internet and the emergence and popularity of various new information technologies, such as smartphones, tablets and APP (Application) products, the word "New media" arouses the public attention, reflecting the characteristics of modern time. Its connotation is the use of computer technology, internet technology and mobile terminal technology and digital information transmission technology to achieve timeliness, comprehensiveness, interactivity and globalization of information transmission. College students on the stand of times must be affected by the new media comprehensively, so college English teaching is no exception.

In 2004, the Ministry of Education issued "College English Curriculum Teaching Requirements (Trial)” and clearly put forward network multimedia teaching should be promoted in college English teaching and the current teaching mode should be transformed as an integrity of network, teaching software and classroom teaching. The integrated use of personalized and active learning mode should be encouraged, multimedia and network technology development opportunity should be made full use of and a new teaching mode should be adopted in order to improve the traditional teaching mode. 
Since China issued the reform of college English teaching, a change in the network teaching has been throughout colleges and universities. However, in the transformation from traditional English teaching to network multimedia teaching, new media injects fresh blood to the college English teaching, such as the renewal of learning tools and learning method and the transformation of the teachers and students' English learning ideas. At the same time, this also causes some unavoidable teaching problems. This paper points out the problems existing in college English teaching and analyzes the causes, then discusses and puts forward the corresponding strategies for the transformation of college English teaching.

\section{The problems existing in the transformation of college English teaching}

The application of network multimedia technology in college English teaching enables college English teachers to be free from the onerous lectures in the classroom teaching, which is beneficial to the interaction between teachers and students.

Students develop their interest in the new classroom form and the classroom atmosphere will be transformed accordingly, but some problems are also exposed in the transformation period. For instance, teacher's ideology in English education doesn't transform completely; students are not good at online communication and emotional communication; there aren't enough qualified staff and the professional level of teachers remains to be further improved; the repository development is not satisfactory and the reform of evaluation system still lags behind. College English multi-media network auxiliary teaching requires the teacher's role to change from a speaker to a guide, that is to say, the teachers needn't conduct a lecture on language knowledge but should organize communicative activities, create individualized lesson, try to be skilled at guiding students to put English into practice and perform as a language and cultural expert. Facing the rapid rise of college English multi-media network auxiliary teaching, many teachers are still restricted by the teaching belief in traditional classroom and cannot be fully concentrated on the preparation of new teaching method.

In addition, although the network multimedia English teaching is the reform of teaching methods and has many advantages, building a network multimedia classroom is more expensive and has greater technical difficulty to compare with the traditional classroom. At the same time, the multimedia teaching is also a challenge for teachers. Teachers must be proficient in computer operation and can integrate the teaching content into the design of the multimedia network courseware with a sense of responsibility and patience.

They should answer the questions online in a timely manner and care program construction. However, have teachers been skilled at making full use of multimedia network? On the one hand, a considerable part of teachers, especially the old whose computer application ability (such as computer operation, access to resources with the aid of network and courseware making) is not strong are difficult to be competent to the work of web-based multimedia teaching. On the other hand, most of the teachers can only carry on demonstration teaching in multimedia classrooms, but are unable to use network or internet resources to serve English teaching.

Multimedia teaching has its own characteristics and advantages, but the bilateral relation between teaching and learning and teacher's perception in teaching students how to think and behave are hard to be realized by the use of multimedia teaching. Therefore, it is an important problem of the current teaching for college English teachers how to select teaching materials which are beneficial to students from a variety of information resources, how to organize these materials in class and present them to the students, how to make full use of computer technology development and teaching software in classroom, how to master computer knowledge, be familiar with computer 
programs and make full use of network resources.

\section{The analysis of the causes of problems in college English teaching transformation}

Since the 1980s, multimedia assistive technology has gradually been introduced and applied into teaching. The combination of text, voice and image to auxiliary teaching helps to promote students to produce strong interest in the teaching content due to its advantages of richness, diversity and interactivity. Multimedia technology has a strong interactivity and passes graph and image data to the students through the projector and computer, which can achieve a good human-computer interaction and is beneficial to the improvement of classroom atmosphere and students' enthusiasm. However, in the process of multimedia teaching, some problems are also exposed.

(1) Internal cause analysis. College English teaching in China has a long history, so in a long-term, teachers in college follow the traditional teaching mode and it is difficult to realize the change of nature in traditional teaching in a short period of time. Most college English teachers, under influence of the traditional "teacher-centered" teaching mode, have formed an entrenched and centralized teaching idea and practice. Investigating the root causes, our country's modern English teaching theory is deemed from western countries or draws lessons from western experience, which is more affected by the grammar translation teaching mode. Grammar Translation Method, also known as The Traditional or Classical Method, is the oldest and the most far-reaching method system in foreign language teaching history. This kind of teaching method advocates that a foreign language should be taught with the help of native language. Translation is regarded as the basic means in the teaching process and grammar is the fundamental way to introduce new language, emphasizing the central position of grammar in the teaching but belittling the cultivation of listening and speaking skills. This teaching mode has certain effect in basic learning and is simple and easy to operate. Despite the criticism, Grammar Translation Method is profound in our country. Another limiting factor of the English teaching mode in our country is the learning evaluation system of our country. The national education policy sees English as a basic content of national education. We should give no cause for much criticism to the national education policy that English language ability should be seen as a kind of basic quality of students, however, teaching mode for the purpose of exam-orientation is also causing the deviation of learning English at the same time. From elementary school, middle school to college, tests become the ultimate measure of evaluating students' skills in English. Under this pattern, Chinese students often have a high level in written English rather than in oral English ability. Teachers' change of teaching concepts is restricted by various factors such as their own knowledge background, school teaching ideas and students' level of English. So, it must be a long process for teachers to transform their teaching concepts.

(2) The external cause analysis. Although multimedia technology enables teachers to be liberated from the hard work of traditional teaching, but its implementation is also restricted by objective conditions. First of all, multimedia hardware investment needs corresponding financial support. Network teaching is to claim the aid of forming a complete set of computer equipment and network environment, which all need school spending. Although the expansion of the scale of enrollment in colleges and universities leads to the significant increase in school funding, the expansion the scale of enrollment means to increase the construction of infrastructure, engaging in scientific research and providing teachers treatment, etc. Therefore, funds are always short to contribute to the construction of multimedia. The lack of hardware conditions makes teaching reform tend to talk. In addition, the evaluation mechanism of learning English is still exam-oriented. Also as a result of college expansion of the scale of enrollment and the sharp surge of college students in our country, 
college students are facing unprecedented pressure in employment. Under the fierce competition, how to stand out from the many job seekers, English certificates for CET 4 and CET 6 become the key of graduate employment. Employment rate affects the lifeblood of colleges and universities at present. Under the employment pressure, students are studying for the exam and teachers can only guide teaching according to the level rate, which further makes teaching reform walk with difficult.

\section{The countermeasures to resolve the problem in the transformation of teaching}

(1) Changing the traditional teaching idea . Under the new form of teaching, teachers should establish new teaching ideas to adapt to the demand of times. Modern education theory believes that teaching is a process of participation to explore new knowledge between teachers and students, so teachers should abandon the traditional "teacher-centered" and "knowledge centered" teaching notions and shouldn't only pay attention to knowledge and neglect students' participation in the teaching mode. In college English teaching, students and teachers are supposed to establish equal partnership, which is an embodiment of bilateral teaching. In teaching activities, teachers play the role of guides, planners and organizers, and are also responsible for the cultivation of students. When making teaching plan, teachers should fully consider the characteristics of students and their nature of development and conform to the actual needs of students. In the practice of teaching, teachers should take all the students as the main body and give full play to their subjective initiative. Through the application of network multimedia, it is possible to stimulate students' interest in learning. What must be noticed is that teachers cannot simply become a courseware player, regardless of the student's participation. Instead, they should combine the actual situation to apply multimedia and network resources reasonably and realize the optimal teaching effect. Teacher can also check the homework, answer questions and organize phase test through online homework, so as to effectively guide students' autonomous learning, which is conductive to the cultivation of the students' English comprehensive skills.

(2) Clear and define learning motivation

According to the source of motivation, learning motivation can be divided into internal motivation and external motivation. Research shows that the internal motivation can help students effectively involve into learning activities at school, and students who have strong internal motivation have the autonomy and spontaneity to gain the knowledge experience. Students who have strong external motivation of learning are induced and passive, showing lower interest in learning spontaneously. College English teachers should help students to clear and define the purpose of learning English and set up a positive and correct learning motivation. At present, English teaching in China has deviated from the real purpose of learning and often gets into the exam-oriented circle. In English teaching, teachers should make students be aware of the role of language in communication and acquire new knowledge through applying English in various fields. Teachers are also supposed to consciously cultivate students' autonomous learning consciousness and help students explore the mode of autonomous learning, play to the subjective initiative, change the traditional concept of learning and finally learn English actively and pleasantly.

(3) Establish a perfect evaluation system

Evaluation system directly affects the teaching activities. Bachman (1990) argued that evaluation is an important link in teaching through the whole teaching process. Ultimate evaluation mode should be an integrated model of formative assessment and summative evaluation and the proportion of procedural evaluation should be improved the process of overall evaluation. For example, students' classroom performance (attendance and discussion) and the use of network platform (online assignment and online discussion) should be included into the final grade in order to improve students' participation. In the practice of teaching, teachers should timely guide students to use network platform for autonomous learning in order to improve their learning initiative. For 
self-discipline ability of poor students, teachers should give timely reminder and supervision. All in all, network learning archives can well reflect the situation of student learning, so teachers can timely adjust the teaching plan combining with the actual situation, so as to help students improve learning methods, encourage their enthusiasm for learning and improve learning progress at last. The increase of proportion of procedural evaluation helps to ensure the impartiality and sustainability of the learning evaluation, which in turn will also promote teaching as well as learning.

\section{Conclusion}

Network multimedia English teaching mode acts as a supplement and improvement of traditional teaching, which flexibly creates a good and vivid environment for students learning a language. Its openness, creativity, vividness, richness, useful and interactive features are incomparable to traditional English teaching. This paper makes an in-depth elaboration of the traditional college English teaching problems and countermeasures of transition to the network multimedia era from the two aspects of internal cause and external cause. In the transformation of college English teaching, there are still many problems needed to resolve. The backward education idea, the rigid assessment system and the limitation of teacher resource are the bottleneck of network multimedia English teaching to further deepen the reform. College English teachers should abandon the backward ideas, change their roles, find the orientation of new teaching environment, focus on the future, take full advantage of the interactivity that computer and network technology brings and set up an interactive teaching mode relying on the school network resources and equipment, so as to promote the students' autonomous learning and all-round development of English skills, laying a good foundation for the future work and study.

\section{Reference}

[1] Department of Higher Education. College English Curriculum Requirements [M]. Shanghai: Shanghai Foreign Language Education Press, 2007.

[2]Liang Kun, Wang Ruomei. College English teaching problems and countermeasures research in new media era [J]. Journal of Inner Mongolia Normal University (Education science edition), 2016(6): 134-135.

[3]Wang Shouren, Wang Haixiao. Investigation on the current situation in college English teaching in colleges and universities and college English teaching reform and the development direction[J]. Foreign Languages in China, 2011(5): 4-7.

[4]Levy. Computer-Assisted Language Learning, Context and Conceptualization [M]. Clarendon Press, 1977.

[5]Ellis Rod. Understanding Second Language Acquisition [M]. Oxford University Press, 1985. 